\title{
Autoimmune Phenomenon in Eczema Seborrhoeicum
}

\author{
Isao Hashimoto \\ Department of Dermatology (Prof. Y. Katabira), \\ Hirosaki University School of Medicine, Hirosaki
}

\begin{abstract}
The serum and the involved skin tissue of patients with eezema seborrhoeicum were examined for the antibodies against the scale infusion. Ouchterlony's diffusion-in-gel test was positive in $5(38 \%)$ of 13 cases. In passive cutaneous anaphylaxis, a kind of delayed reaction was observed 24 hours after the challenge. This reaction was positive in $8(62 \%)$ of 13 cases. The specific method of fluorescent antibody demonstrated the specific fluorescence in the granular and basal layers of the involved skin tissue in $4(57 \%)$ of 7 cases. In one of them the fluorescence was weakened after triamcinolone therapy. The active principles responsible for the above positive reactions were called precipitating antibody, passive cutaneous anaphylaxis antibody and cellular antibody, respectively.

From an analysis of the relationship between the above three kinds of antibodies and the clinical pictures, it was inferred that in some cases of eczema seborthoeicum a kind of contact allergy developed to the autologous seborrheic scales. This autoimmune phenomenon may play an important role in generalization and eczematization, or in intractability of the lesions of eczema seborrhoeicum.
\end{abstract}

The cause of intractability of eczema seborrhoeicum (ES) has not yet been fully elucidated, though it was in part made clear by a laborious work of Katabira. ${ }^{1}$ He showed that the rebelliousness to treatment of ES was partly related to the secondary infection of some resistant bacterial strains and the deficiency of vitamin $B_{6}$.

On the other hand, some old Japanese dermatologists, such as Ohno, ${ }^{2}$ Aoki ${ }^{3}$ and Dohi, ${ }^{4,5}$ attached importance to irritation of seborrhoea in pathogenesis or intractability of $\mathrm{ES}$ of the infants. I to $^{6}$ advocated the term "eczema infantum seborrhoigenes" for the type of eczema infantum originating in seborrhoea of the scalp, assuming that excessive accumulation of the seborrhoic scales may lead to abnormal decomposition and that the decomposed matter may act as an allergen to a delicate skin of infants.

In Europe, Darier" already called eczema seborrhoeicum "eczematides". Davies $^{8}$ observed reproduction of the similar lesions following trauma on the intact skin of the patients with ES. Scott, ${ }^{9}$ on the basis of his clinical experience, considered the lesion of ES on the retroauricular region, head and

Received for publication, February 22, 1966.

This investigation was supported by the Grant in Aid from the Ministry of Education. 
face to be allergic. Haxthausen ${ }^{10}$ thought that the secondary distribution and eczematization presumably is an "id" reaction, or a hypersensitivity to the tissues or the tissue products of the skin. Sato ${ }^{11}$ reported that the blood complement activity was reduced in 3 of 4 cases in association with the allergic gingival symptom. Accordingly, the intervention of autosensitization mechanism is suspected in some type of ES.

The present study was undertaken to investigate the role of the seborrheic scales in pathogenesis or intractability of ES.

\section{MATERIALS AND METHODS}

Subjects. The subjects for the present study were 34 patients with ES (Cases 1 34), 21 patients with other skin diseases (Cases 35 55) and 36 normal control subjects (Cases 56 91) (Table 1). Dermatoses other than ES include: contact dermatitis (Case 38), eczema acutum (Case 50), eczema chronicum (Case 51), autosensitization dermatitis (Cases 41, 42, 43 and 54), neurodermatitis disseminata (Case 37), drug eruption (Case 36), herpes zoster (Case 35), lupus vulgairs (Case 47), combustio (Case 46), pityriasis simplex capitis (Case 48), erythema scarlatiniforme desquamativum recidivans (Case 55), erythrodermia exfoliativa subacuta Wilson-Brocq (Case 45), psoriasis vulgaris (Cases 39, 44, 49, 52 and 53) and cicatrical keloid (Case 40).

TABLE 1. Subjects

\begin{tabular}{l|c|c|c|c}
\hline & Group A & Group B & Group C & Total \\
\hline Eczema seborrhoeicum & 7 & 18 & 9 & 34 \\
Other dermatoses & 7 & 11 & 3 & 21 \\
Normal controls & 3 & 29 & 4 & 36 \\
Total & 17 & 58 & 16 & 91
\end{tabular}

Group A: Cases only for examination of anti-scale antibodies in the serum or in the skin.

Group B: Cases only for collection of antigens (scales, nails or bacteria).

Group C: Cases both for examination of the anti-scale antibodies and for collection of the antigens.

Antigens. Morbid scales were collected from those skin lesions of 26 patients with ES and of 14 cases of other dermatoses, which had not been contaminated with any kinds of external medicine. Instead of normal scales, the nail powder was obtained from 33 normal control subjects by scratching the methanolcleansed nails with a clean knife, since Chihara ${ }^{12}$ proved the same antigenicity of the human nail as the normal dandruff in Storm van Leewen's reaction. These scale and nail specimens were treated with Coca's solution ${ }^{13}$ (Fig. 1), to prepare antigen infusions, such as the ES-scale infusions (Ag-ES), the scale infusions of other dermatoses (Ag-OD) and the normal nail infusions (Ag-N) (Table 2). 


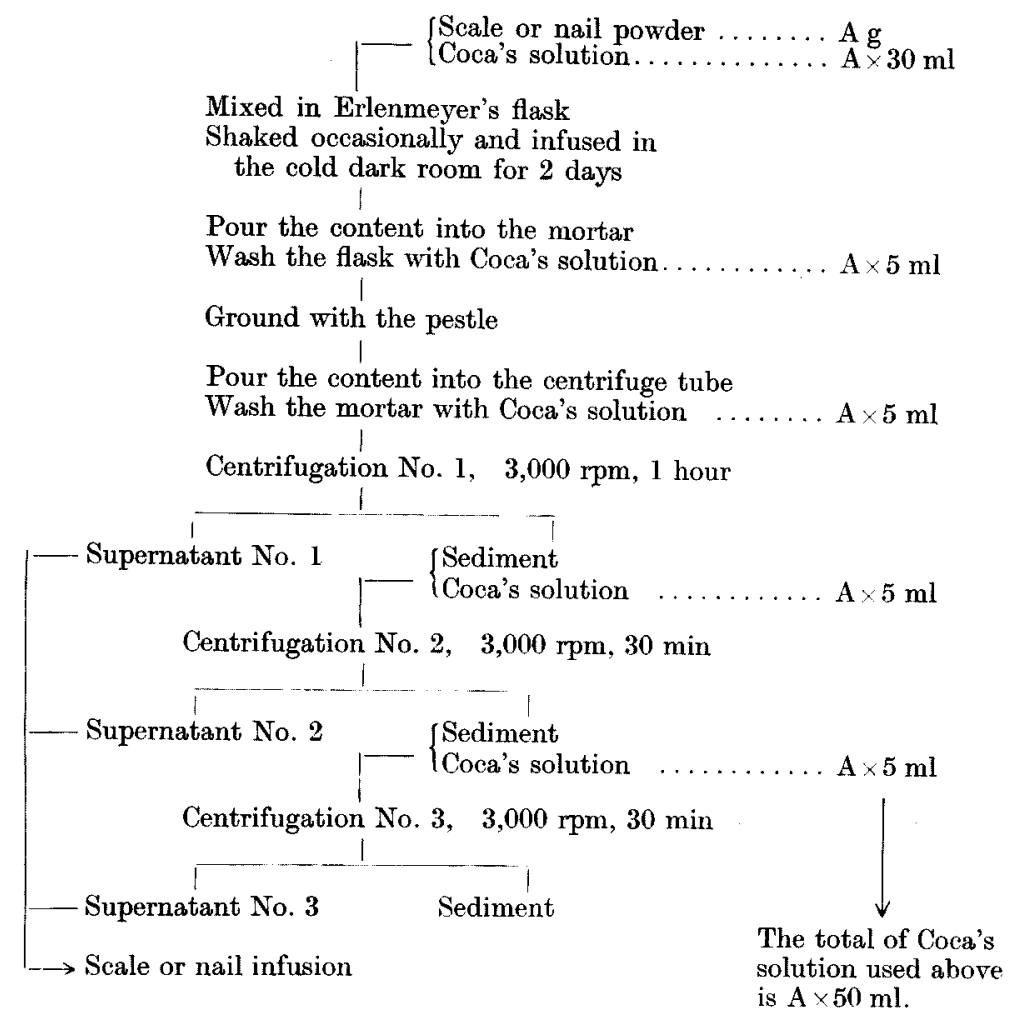

Fig. 1. Preparation of scale and nail infusions.

Chemical analysis of the ES-scale infusion No. 1 (Ag-ES1) revealed that the $\mathrm{pH}$ was 8.4 ; the protein concentration was $2.04 \mathrm{mg} / 100 \mathrm{ml}$. The circular filter paper chromatography according to Nowotny ${ }^{\mathbf{1 4}}$ demonstrated three kinds of unsaturated fatty acid, of which rates of flow (Rf) were $0.81,0.29$ and 0.20 , respectively; the first was thought to be more unsaturated than linolenic acid $(\mathrm{Rf}=0.32)$, and the other two were considered to be less unsaturated than oleic acid $(\mathrm{Rf}=0.35)$. These infusions were stored at $-20^{\circ} \mathrm{C}$ before use.

To examine whether the skin is sensitized by bacteria of secondary infection, two kinds of bacterial antigens were prepared (Table 2). The one was the bacterial culture filtrates, which were the lyophilized filtrates through the Chamberland filter L3 of the bouillon media in which two strains of staphylococcus aureus isolated from the lesions of Cases 5 and 22 were grown for 7 days at $37^{\circ} \mathrm{C}$. The lyophilized filtrates were re-solved in one-tenth of the initial volume using M/100 phosphate buffered saline (PBS), and then used as antigen (Ag-CF). The other was the bacterial colonies of staphylococcus aureus and streptococcus isolated from the lesions of Cases 5, 22 and 23 (Ag-BC). 
TABLE 2. Antigens

\begin{tabular}{|c|c|}
\hline Antigens & Materials \\
\hline $\begin{array}{l}\text { Scale infusions of eczema } \\
\text { seborrhoeicum } \\
\text { No. } 1 \text { (Ag-Esl) } \\
\text { No. } 2(\mathrm{Ag}-\mathrm{ES} 2)\end{array}$ & $\begin{array}{l}3.18 \mathrm{~g} \text { of the scale from Cases } 6 \text { to } 12 \text { and } \\
17 \text { to } 21 . \\
4.61 \mathrm{~g} \text { of the scale from Cases } 13 \text { and } 22 \\
\text { to } 34 .\end{array}$ \\
\hline $\begin{array}{l}\text { Scale infusions of other } \\
\text { dermatoses } \\
\text { No. } 1 \text { (Ag-OD1) } \\
\text { No. } 2 \text { (Ag-OD2) } \\
\text { No. } 3 \text { (Ag-OD3) }\end{array}$ & $\begin{array}{l}10 \mathrm{mg} \text { of the scale from Case } 45 . \\
20 \mathrm{mg} \text { of the scale from Case } 38 . \\
3.5 \mathrm{~g} \text { of the scale from Cases } 39,43 \text { and } \\
46 \text { to } 55 .\end{array}$ \\
\hline $\begin{array}{c}\text { Nail infusions of normal controls } \\
\text { Blood type O (Ag-NO) } \\
\text { Blood type A (Ag-NA) } \\
\text { Blood type B (Ag-NB) } \\
\text { Various blood types No. } 1 \\
\text { (Ag-NABO1) } \\
\text { Various blood types No. } 2 \\
\text { (Ag-NABO2) }\end{array}$ & $\begin{array}{l}49 \mathrm{mg} \text { of the nail powder from Case } 63 . \\
45 \mathrm{mg} \text { of the nail powder from Case } 59 . \\
20 \mathrm{mg} \text { of the nail powder from Case } 60 . \\
0.61 \mathrm{~g} \text { of the nail powder from Cases } 57 \text {, } \\
58 \text { and } 64 \text { to } 71 \text {. } \\
0.34 \mathrm{~g} \text { of the nail powder from Cases } 72 \\
\text { to } 91 .\end{array}$ \\
\hline $\begin{array}{l}\text { Bacterial culture filtrates } \\
\text { No. } 1 \text { (Ag-CF1) } \\
\text { No. } 2 \text { (Ag-CF2) }\end{array}$ & $\begin{array}{l}\text { Filtrates of the bouillon media used for } \\
\text { a strain of staph. aureus from Case } 5 \text {. } \\
\text { Filtrates of the bouillon media used for } \\
\text { a strain of staph. aureus from Case } 22 \text {. }\end{array}$ \\
\hline $\begin{array}{l}\text { Bacterial colonies } \\
\text { No. } 1 \text { (Ag-BCl) } \\
\text { No. } 2(\mathrm{Ag}-\mathrm{BC} 2) \\
\text { No. } 3(\mathrm{Ag}-\mathrm{BC} 3)\end{array}$ & $\begin{array}{l}\text { Colonies of staph. aureus from Case } 5 \text {. } \\
\text { Colonies of staph. aureus from Case } 22 \text {. } \\
\text { Colonies of streptococcus from Case } 23 \text {. }\end{array}$ \\
\hline
\end{tabular}

Sera. The serum was obtained from 14 cases of ES (Cases 1-14), 6 of other dermatoses (Cases 35-40), and 5 normal controls including 3 subjects of the blood type 0 (Cases 56-58), 1 of the type A (Case 59) and 1 of the type B (Case 60).

Skin tissue sections. Skin specimens were obtained under local anesthesia from the lesions of 7 cases of ES (Cases 3, 9 to 12, 15 and 16), 3 of autosensitization dermatitis (Cases 41-43) and 2 of psoriasis vulgaris (Cases 39 and 44). Control specimens were taken from the scalp of 2 healthy individuals (Cases 61 and 62). In Case 9, another specimen was obtained after treatment with $452 \mathrm{mg}$ of triamcinolone. These specimens, having been quickly frozen at $-70^{\circ} \mathrm{C}$, were cut into sections from 8 to 10 microns thick with a microtome in a cryostat at $-20^{\circ} \mathrm{C}$. These sections were attached to cover slips, fixed in $95 \%$ ethanol at $37^{\circ} \mathrm{C}$ for 15 minutes, and processed to fluorescent staining.

Ouchterlony's diffusion-in-gel method. On a gel plate made of $1.5 \%$ agar solution, seven wells of $5 \mathrm{~mm}$ in diameter were set, corresponding to the 
positions of the center and all the vertices of the regular hexagon with a $10 \mathrm{~mm}$ side. A small amount of an antigen infusion was poured into the central well. Five of the six peripheral wells were filled with the twofold dilutions of serum, and the last peripheral well with PBS as control. Combinations of the antigens and the sera are presented in Table 3. The examined sera were those of 13 cases of ES (Cases 1-13), 5 of other dermatoses (Cases 35-39) and 4 healthy controls (Cases 56, 57, 59 and 60). Agar plates were then placed in a closed, humid chamber at $37^{\circ} \mathrm{C}$. The reaction was assessed once daily, for 7 days. The intensity of reaction was rated as follows: (-), no precipitation line; (+), a precipitation line was produced only to the undiluted serum well; and $(2+)$, a precipitation line was present up to the $1: 2$ dilution. Reactions intenser than $(2+)$ were not observed in the present study. The reaction between the bacterial colonies and the sera was examined not by Ouchterlony's method, but by the agglutination test on a slide glass, since the colonies were not a liquid antigen.

Passive cutaneous anaphylaxis (PCA). The method by Aswaq et al. ${ }^{15}$ was employed. Combinations of the antigens and the sera are shown in Table 4. The sera of 13 cases of ES (Cases 1 to 8 and 10 to 14), 3 of other dermatoses (Cases 3840) and 2 healthy subjects (Cases 57 and 58) were used undiluted. According to the observations by Aswaq et al., the reaction was read 24 hours after the challenge. Mainly based on the degree of induration, the intensity of reaction was graded as follows: $(-)$, no reaction, or the same reaction as control; $(+)$, a reaction intenser than control; and $(2+)$, a reaction far intenser than control. After reading of the reaction the animals were sacrificed with chloroform vapor, and the reaction sites were excised for histological examination with hematoxylin-eosin stain.

\section{Fluorescent antibody staining}

Complement method. The method by Ishida and Hinuma ${ }^{16,17}$ was employed. The fluorescent anti-complement antibody (Anti-C'*) prepared for the present study had the $\mathrm{F} / \mathrm{P}$ ratio of $3.42 \times 10^{-3}$ and the staining titer of $1: 40$. In each specimen a main and six control experiments were carried out (Table 5). The examined skin specimens are listed in Table 6. Because the weak yellowgreen fluorescence in control sections was not completely removed by various combinations of the optical filters, the fluorescence observed was classified as follows: $(3+)$, intense yellow-green fluorescence; $(2+)$, moderate yellow-green fluorescence; $(+)$, weak yellow-green fluorescence; $(\mathrm{Y}+)$, yellow fluorescence; and $(\mathrm{R} \pm)$, weak dark-red fluorescence.

Specific method. The ES-scale infusion No. 1 (Ag-ES1) was concentrated to one-third of the starting volume by evaporation with a fan at the room temperature, emulsified with complete adjuvant, and injected subcutaneously to the back of rabbits. A series of immunization was composed of $2.5 \mathrm{ml}$ for the first 
injection and $3.5 \mathrm{ml}$ for the remaining 4 injections. The antiserum thus obtained showed a precipitation titer of $1: 128$. By labeling this antiserum with fluorescent isothiocyanate according to the technique of Ishida and Hinuma, ${ }^{16}$ an anti-ES-scale fluorescent antibody (Anti-ES*) was prepapred, of which F/P ratio was $4.1 \times 10^{-3}$. In staining, the $1: 32$ dilution was used. The control was the same dilution of the non-labeled antiserum (Anti-ES ${ }^{\circ}$. In each specimen a main and seven control experiments were carried out (Table 5). The exmained specimens are listed in Table 7. The sections reacted with the antigens and then, with Anti-ES*. The other procedures were essentially the same as in the complement method described by Ishida and Hinuma. ${ }^{17}$ The rests of the frozen specimens were put back into $10 \%$ formalin and processed to hematoxylin-eosin stain.

\section{RESULTS}

Ouchterlony's diffusion-in-gel method (Table 3 and Fig. 2)

In $5(38 \%)$ of 13 patients and $1(8 \%)$ of 12 patients with ES the sera showed a positive reaction against $\mathrm{Ag}-\mathrm{ES} 1$ and $\mathrm{Ag}-\mathrm{NA}$, respectively. The agglutination test against $\mathrm{Ag}-\mathrm{BC} 3$ was positive in $1(20 \%)$ of 5 cases of ES. The other reactions were all negative. The percentage of the positive reaction $(38 \%)$ shown by the sera of patients with ES against Ag-ES1, although insignificant at 5\% level, was considerably high, as compared with the other percentages.

\section{PCA (Table 4 and Fig. 3)}

The reactions against $\mathrm{Ag}-\mathrm{ES} 2, \mathrm{AG}-\mathrm{OD} 3$ and $\mathrm{Ag}-\mathrm{NABO}$ were positive in 8

TABLE 3. Results of diffusion-in-gel method

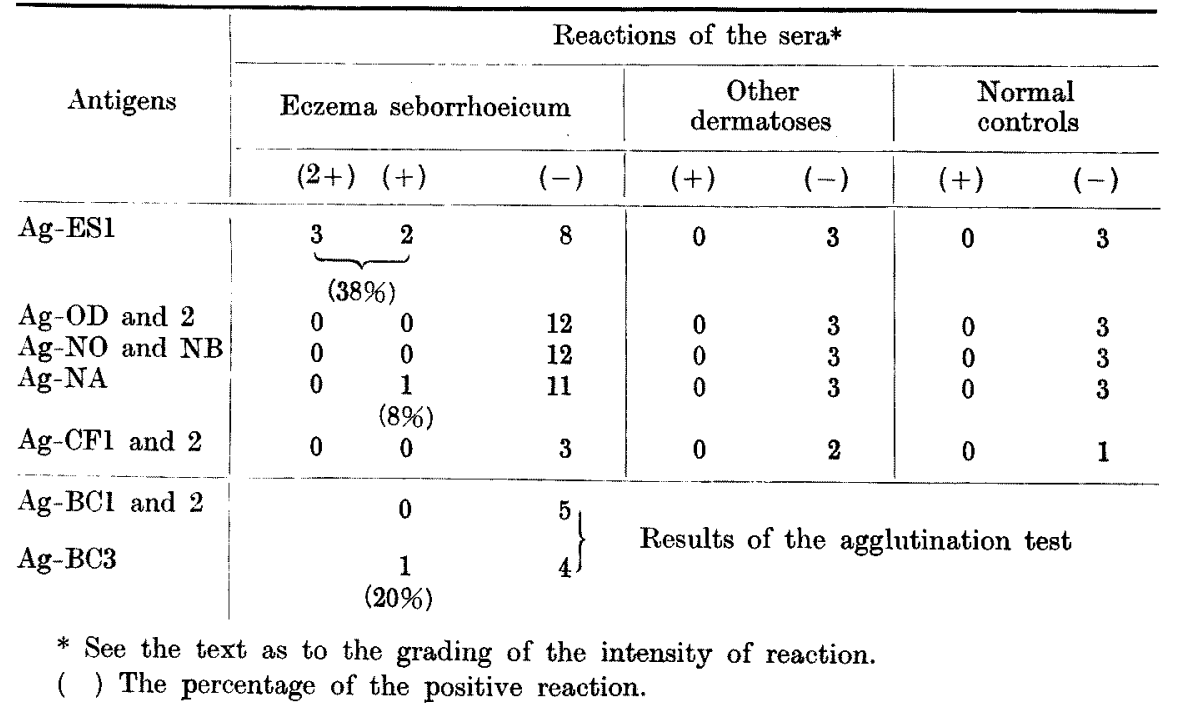


TaBle 4. Results of passive cutaneous anaphylaxis

\begin{tabular}{|c|c|c|c|c|c|c|}
\hline \multirow{3}{*}{ Antigens } & \multicolumn{6}{|c|}{ Reactions of the sera* } \\
\hline & \multicolumn{2}{|c|}{ Eezema seborrhoeicum } & \multicolumn{2}{|c|}{$\begin{array}{c}\text { Other } \\
\text { dermatoses }\end{array}$} & \multicolumn{2}{|c|}{$\begin{array}{l}\text { Normal } \\
\text { controls }\end{array}$} \\
\hline & $(2+) \quad(+)$ & $(-)$ & $(+)$ & $(-)$ & $(+)$ & $(-)$ \\
\hline $\mathrm{Ag}-\mathrm{ES} 2$ & $\underbrace{1 \quad 7}_{(62 \%)}$ & 5 & 0 & 1 & 0 & 1 \\
\hline $\mathrm{Ag}-\mathrm{OD} 3$ & $\begin{array}{cc}0 & 1 \\
(33 \%)\end{array}$ & 2 & 0 & 2 & 0 & 1 \\
\hline Ag-NABOI & $\begin{array}{c}1 \\
(8 \%)\end{array}$ & 12 & $\stackrel{2}{(67 \%)}$ & 1 & 0 & 2 \\
\hline
\end{tabular}

* See the text as to the grading of the intensity of reaction.

( ) The percentage of the positive reaction.

TABLE 5. Reaction components of the main and control experiments of fluorescent antibody staining

A) Complement method

\begin{tabular}{|c|c|c|c|}
\hline $\begin{array}{l}\text { Section } \\
\text { No. }\end{array}$ & $\begin{array}{l}\text { Antigen } \\
\text { part }\end{array}$ & $\begin{array}{l}\text { Complement } \\
\text { part }\end{array}$ & $\begin{array}{l}\text { Part of fluorescent anti-complement } \\
\text { antibody }\end{array}$ \\
\hline $\begin{array}{l}1 \\
2 \\
3 \\
4 \\
5 \\
6 \\
7\end{array}$ & $\begin{array}{l}\mathrm{Ag}-\mathrm{ES} 1 \\
\mathrm{Ag}-\mathrm{ES} 1 \\
\mathrm{Ag}-\mathrm{ES} 1 \\
\mathrm{Ag}-\mathrm{ES} 1 \\
\mathrm{Ag}-\mathrm{NABO2} \\
\text { PBS } \\
(-)\end{array}$ & $\begin{array}{l}\text { C' } \\
C^{\prime} \\
C^{\prime} \\
\text { PBS } \\
\text { C' } \\
\text { PBS } \\
(-)\end{array}$ & $\begin{array}{l}\text { Anti-C'* } \\
\text { Anti-C'० } \\
\text { Anti-C'० followed by Anti-C'* } \\
\text { Anti-C'* } \\
\text { Anti-C'* } \\
\text { Anti-C'- } \\
\quad(-)\end{array}$ \\
\hline
\end{tabular}

B) Specific method

\begin{tabular}{c|c|c}
\hline Section No. & Antigen part & Part of fluorescent anti-ES scale antibody \\
\hline 1 & Ag-ES1 & Anti-ES* \\
$\mathbf{2}$ & Ag-ES1 & Anti-ES \\
3 & Ag-ES1 & Anti-ES ${ }^{\circ}$, followed by Anti-ES* \\
4 & Ag-NABO2 & Anti-ES* \\
5 & Ag-NABO2 & Anti-ES \\
6 & PBS & Anti-ES* \\
7 & PBS & Anti-ES \\
8 & $(-)$ & $(-)$
\end{tabular}

C': Complement

Anti-C'*: Fluorescent anti-complement antibody

Anti-C': Nonlabeled anti-complement antibody

Anti-ES*: Fluorescent anti-ES scale antibody

Anti-ES ${ }^{\circ}$ : Non-labeled anti-ES scale antibody

PBS: M/100 phosphate buffered saline 
TABLE 6. Results of fluorescent antibody staining (complement method)

\begin{tabular}{|c|c|c|c|c|c|c|c|c|}
\hline \multirow{3}{*}{ Specimen } & \multirow{3}{*}{$\begin{array}{l}\text { Section } \\
\text { No. }\end{array}$} & \multicolumn{7}{|c|}{ Fluorescence* } \\
\hline & & \multicolumn{4}{|c|}{ Epidermist } & \multicolumn{3}{|c|}{ Dermis $§$} \\
\hline & & $\mathrm{CO}$ & GR & SP & $\mathrm{BA}$ & $\mathbf{P A}$ & SU & RE \\
\hline $\begin{array}{l}\text { Eczema seborrhoeicum } \\
\text { (Cases } 10 \text { and } 11 \text { ) }\end{array}$ & $\begin{array}{c}1 \\
2,3 \\
4 \\
5 \\
6 \\
7\end{array}$ & $\begin{array}{r}3+ \\
+ \\
2+ \\
3+ \\
2+ \\
+\end{array}$ & $\begin{array}{r}3+ \\
+ \\
2+ \\
3+ \\
2+ \\
+\end{array}$ & $\begin{array}{r}2+ \\
R_{ \pm} \\
+ \\
2+ \\
+ \\
-\end{array}$ & $\begin{array}{r}3+ \\
R_{ \pm} \\
+ \\
3+ \\
+ \\
-\end{array}$ & $\begin{array}{l}+ \\
+ \\
+ \\
+ \\
+ \\
-\end{array}$ & $\begin{array}{l}+ \\
+ \\
+ \\
+ \\
+ \\
-\end{array}$ & $\begin{array}{l}+ \\
+ \\
+ \\
+ \\
+ \\
-\end{array}$ \\
\hline $\begin{array}{l}\text { Autosensitization } \\
\text { dermatitis } \\
\text { (Case 41) }\end{array}$ & $\begin{array}{c}1 \\
2,3,4 \\
5 \\
6 \\
7\end{array}$ & $\begin{array}{c}2+ \\
2+ \\
2+ \\
2+ \\
+\end{array}$ & $\begin{array}{l}2+ \\
2+ \\
2+ \\
2+ \\
+\end{array}$ & $\begin{array}{c}3+ \\
2+ \\
3+ \\
2+ \\
-\end{array}$ & $\begin{array}{l}3+ \\
2+ \\
3+ \\
2+ \\
-\end{array}$ & $\begin{array}{l}+ \\
+ \\
+ \\
+ \\
-\end{array}$ & $\begin{array}{l}3+ \\
2+ \\
3+ \\
2+ \\
-\end{array}$ & $\begin{array}{l}+ \\
+ \\
+ \\
+ \\
-\end{array}$ \\
\hline $\begin{array}{l}\text { Normal control } \\
\text { (Case 61) }\end{array}$ & $\begin{array}{c}1 \\
2,3 \\
4 \\
5 \\
6 \\
7\end{array}$ & $\begin{array}{r}2+ \\
+ \\
+ \\
2+ \\
+ \\
+\end{array}$ & $\begin{array}{r}2+ \\
+ \\
+ \\
2+ \\
+ \\
+\end{array}$ & $\begin{array}{l}+ \\
- \\
+ \\
+ \\
+ \\
-\end{array}$ & $\begin{array}{l}+ \\
- \\
+ \\
+ \\
+ \\
-\end{array}$ & $\begin{array}{l}+1 \\
- \\
+ \\
+ \\
+ \\
-\end{array}$ & \begin{tabular}{l|l}
+ \\
- \\
+
\end{tabular} & $\begin{array}{l}+ \\
- \\
+ \\
+ \\
+ \\
-\end{array}$ \\
\hline \multicolumn{2}{|c|}{$\begin{array}{l}\text { * Classification of fluorescence } \\
\begin{array}{l}3+\text { Strong } \\
2+\text { Moderate } \\
+ \text { Yeallow-green } \\
\text { - No fluorescence }\end{array}\end{array}$} & \multicolumn{2}{|c|}{$\dagger$ Epidermis } & $\begin{array}{c}\mathrm{CO} \\
\mathrm{GR} \\
\mathrm{SP} \\
\mathrm{BA} \\
\mathrm{PA} \\
\mathrm{SU} \\
\mathrm{RE}\end{array}$ & $\begin{array}{l}\text { Stra } \\
\text { Str. } \\
\text { Str. } \\
\text { Str. } \\
\text { Str. } \\
\text { Str. } \\
\text { Str. }\end{array}$ & $\begin{array}{l}m \text { corr } \\
\text { ranulo } \\
\text { pinosur } \\
\text { asale } \\
\text { apillar } \\
\text { abpapi } \\
\text { ticula }\end{array}$ & $\begin{array}{l}\text { neum } \\
\text { sum } \\
\text { n } \\
\text { e } \\
\text { llare } \\
\text { re }\end{array}$ & \\
\hline
\end{tabular}

$(62 \%)$ of 13 cases, $1(33 \%)$ of 3 cases and $1(8 \%)$ of 13 cases of ES, respectively. In $2(67 \%)$ of 3 patients with other dermatoses, the serum showed a positive reaction against $\mathrm{Ag}-\mathrm{NABO}$. The other reactions were all negative. The incidence of the positive reaction $(62 \%)$ provoked by the sera of seborrheic patients against Ag-ES2 was significantly higher at $5 \%$ level than that of the positive reaction against $\mathrm{Ag}-\mathrm{NABO1}$, and it was, though statistically insignificant, much higher than the percentage of the positive reaction against Ag-OD3. Histological examination of the sites of positive reaction revealed marked vascular dilatation with lymphocytic infiltration, as compared with control sites.

\section{Fluorescent antibody staining}

The sebaceous gland as a rule showed yellow fluorescence $(Y+)$. The kind of fluorescence of the hair root and the inner hair sheath was the same as that of the horny layer. The outer hair sheath showed the same kind of fluorescence as the reticular layer. The sweat gland and the blood capillaries were not fluorescent. The results of staining in the other parts may be summarized as 
TABLE 7. Results of fluorescent antibody staining (specific method)

\begin{tabular}{|c|c|c|c|c|c|c|c|c|}
\hline \multirow{3}{*}{ Specimen } & \multirow{3}{*}{$\begin{array}{l}\text { Section } \\
\text { No. }\end{array}$} & \multicolumn{7}{|c|}{ Fluorescence* } \\
\hline & & \multicolumn{4}{|c|}{ Epidermis $†$} & \multicolumn{3}{|c|}{ Dermis } \\
\hline & & $\mathrm{CO}$ & GR & $\mathrm{SP}$ & $\mathbf{B A}$ & PA & $\mathrm{SU}$ & $\mathrm{RE}$ \\
\hline $\begin{array}{l}\text { Eczema seborrhoeicum } \\
\text { (ES), the }(+) \text { group } \\
\text { (Cases } 9,12,15 \text { and } 16 \text { ) }\end{array}$ & $\begin{array}{c}1 \\
2,3 \\
4 \\
5 \\
6 \\
7.8\end{array}$ & $\begin{array}{r}2+ \\
+ \\
2+ \\
+ \\
2+ \\
-\end{array}$ & $\begin{array}{r}3+ \\
+ \\
2+ \\
+ \\
2+ \\
-\end{array}$ & $\begin{array}{r}- \\
+ \\
2+ \\
+ \\
2+ \\
-\end{array}$ & $\begin{array}{r}3+ \\
+ \\
2+ \\
+ \\
2+ \\
-\end{array}$ & $\begin{array}{l}+ \\
+ \\
+ \\
+ \\
+ \\
+\end{array}$ & $\begin{array}{l}+ \\
+ \\
+ \\
+ \\
+ \\
+\end{array}$ & $\begin{array}{l}+ \\
+ \\
+ \\
+ \\
+ \\
+\end{array}$ \\
\hline $\begin{array}{l}\mathrm{ES}, \text { the }( \pm) \text { group } \\
\text { (Case } 3 \text { and Case } 9 \\
\text { after treatment) }\end{array}$ & $\begin{array}{c}1 \\
2,3 \\
4 \\
5,6 \\
7,8\end{array}$ & $\begin{array}{r}2+ \\
+ \\
2+ \\
+ \\
-\end{array}$ & $\begin{array}{r}2+ \\
+ \\
2+ \\
+ \\
-\end{array}$ & $\begin{array}{r}2+ \\
+ \\
2+ \\
+ \\
-\end{array}$ & $\begin{array}{r}2+ \\
+ \\
2+ \\
+ \\
-\end{array}$ & $\begin{array}{l}+ \\
+ \\
+ \\
+ \\
+\end{array}$ & $\begin{array}{l}+ \\
+ \\
+ \\
+ \\
+\end{array}$ & $\begin{array}{l}+ \\
+ \\
+ \\
+ \\
+\end{array}$ \\
\hline $\begin{array}{l}\text { ES, the }(-) \text { group } \\
\text { (Cases } 10 \text { and } 11 \text { ) and } \\
\text { autosensitization } \\
\text { dermatitis, the (-) } \\
\text { group (Cases } 41 \text { and } \\
\text { 43) }\end{array}$ & $\begin{array}{c}1 \\
2,3 \\
4 \\
5 \\
6 \\
7,8\end{array}$ & $\begin{array}{l}+ \\
- \\
+ \\
- \\
+ \\
-\end{array}$ & $\begin{array}{l}+ \\
- \\
+ \\
- \\
+ \\
-\end{array}$ & $\begin{array}{l}+ \\
- \\
+ \\
- \\
+ \\
-\end{array}$ & $\begin{array}{l}+ \\
- \\
+ \\
- \\
+ \\
-\end{array}$ & $\begin{array}{l}+ \\
+ \\
+ \\
+ \\
+ \\
+\end{array}$ & $\begin{array}{l}+ \\
+ \\
+ \\
+ \\
+ \\
+\end{array}$ & $\begin{array}{l}+ \\
+ \\
+ \\
+ \\
+ \\
+\end{array}$ \\
\hline $\begin{array}{l}\text { Autosensitization } \\
\text { dermatitis, the }( \pm) \\
\text { group (Case 42) }\end{array}$ & $\begin{array}{c}1 \\
2,3 \\
4 \\
5 \\
6 \\
7,8\end{array}$ & $\begin{array}{r}2+ \\
+ \\
2+ \\
- \\
+ \\
-\end{array}$ & $\begin{array}{r}2+ \\
+ \\
2+ \\
- \\
+ \\
-\end{array}$ & $\begin{array}{l}+ \\
+ \\
+ \\
- \\
+ \\
-\end{array}$ & $\begin{array}{l}+ \\
+ \\
+ \\
- \\
+ \\
-\end{array}$ & $\begin{array}{l}+ \\
+ \\
+ \\
+ \\
+ \\
+\end{array}$ & $\begin{array}{r}2+ \\
+ \\
2+ \\
+ \\
+ \\
+\end{array}$ & $\begin{array}{l}+ \\
+ \\
+ \\
+ \\
+ \\
+\end{array}$ \\
\hline $\begin{array}{l}\text { Psoriasis vulgaris } \\
\text { (Cases } 39 \text { and 44) }\end{array}$ & $\begin{array}{c}1 \\
2,3 \\
4 \\
5 \\
6 \\
7,8\end{array}$ & $\begin{array}{r}R \pm \\
- \\
+ \\
- \\
+ \\
-\end{array}$ & $\begin{array}{l}- \\
- \\
+ \\
- \\
+ \\
-\end{array}$ & $\begin{array}{l}- \\
\overline{+} \\
- \\
+ \\
-\end{array}$ & $\begin{array}{l}- \\
\overline{+} \\
- \\
+ \\
-\end{array}$ & $\begin{array}{l}+ \\
+ \\
+ \\
+ \\
+ \\
+\end{array}$ & $\begin{array}{l}+ \\
+ \\
+ \\
+ \\
+ \\
+\end{array}$ & $\begin{array}{l}+ \\
+ \\
+ \\
+ \\
+ \\
+\end{array}$ \\
\hline $\begin{array}{l}\text { Normal control } \\
\text { (Case 62) }\end{array}$ & $\begin{array}{c}1 \\
2,3 \\
4 \\
5 \\
6 \\
7,8\end{array}$ & $\begin{array}{l}+ \\
+ \\
+ \\
+ \\
+ \\
-\end{array}$ & $\begin{array}{r}+ \\
- \\
+ \\
- \\
+ \\
\mathbf{R} \pm\end{array}$ & $\begin{array}{r}+ \\
- \\
+ \\
- \\
+ \\
\mathbf{R} \pm\end{array}$ & $\begin{array}{r}+ \\
- \\
+ \\
- \\
+ \\
R \pm\end{array}$ & $\begin{array}{l}+ \\
+ \\
+ \\
+ \\
+ \\
+\end{array}$ & $\begin{array}{l}+ \\
+ \\
+ \\
+ \\
+ \\
+\end{array}$ & $\begin{array}{l}+ \\
+ \\
+ \\
+ \\
+ \\
+\end{array}$ \\
\hline
\end{tabular}

$\left.\begin{array}{l}* \\ \uparrow\end{array}\right\}$ See the footnotes of Table 6.

follows:

1) Complement method (Table 6 and Fig. 4): In general, the most intense fluorescence was observed in Sections 1 and 5 , which was $(2+)$ in the healthy control, and $(3+)$ in patients with ES or with autosensitization dermatitis. The 
fluorescence in $(3+)$ was observed in the squamous cell, the basal and the subpapillary layer in autosensitization dermatitis; in the horny, the granular and the basal layer; and in the inner hair sheath in ES. But the $(3+)$ fluorescence was considered to be nonspecific, because it was present not only in the control experiment (Section 5), but also in some sections of autosensitization dermatitis.

2) Specific method (Table 7 and Fig. 5): According to the most intense yellow-green fluorescence observed in the main experiments (Section 1), the patients with ES or with autosensitization dermatitis were divided into the $(+)$ group, in which the strongest fluorescence was $(3+)$; the $( \pm)$ group, in which the strongest was $(2+)$; and the (-) group showing weaker fluorescence. In the sections of two patients with psoriasis vulgaris and a normal control, the fluorescence was generally weak. The $(+)$ group was exclusively occupied by some patients with ES. The $(3+)$ fluorescence of this group was observed in the granular and the basal layer in Section 1, and nearly completely blocked in the blocking test (Section 3). Therefore, it was considered to be specific fluorescence. This specific fluorescence was observed in $4(57 \%)$ of 7 cases of ES. In Case 9, the clinical improvement by triamcinolone therapy was associated with reduction of the yellow-green fluorescence in the skin tissue. The findings of the specific method of fluorescent antibody staining were not related to those of hematoxylin-eosin staining.

TABLE 8. Clinical pictures and anti-eczema

\begin{tabular}{|c|c|c|c|c|c|c|c|c|c|}
\hline $\begin{array}{l}\text { Case } \\
\text { No. }\end{array}$ & Sex & $\begin{array}{l}\text { Age } \\
\text { (yrs) }\end{array}$ & $\begin{array}{l}\text { Distribu- } \\
\text { tion of } \\
\text { the lesion }\end{array}$ & $\begin{array}{l}\text { Nature } \\
\text { of the } \\
\text { lesion }\end{array}$ & $\begin{array}{l}\text { Pedness } \\
\text { of the } \\
\text { lesion }\end{array}$ & $\left|\begin{array}{l}\text { Scale } \\
\text { of the } \\
\text { lesion }\end{array}\right|$ & $\begin{array}{c}\text { Bacteria } \\
\text { of } \\
\text { secondary } \\
\text { infection }\end{array} \mid$ & $\begin{array}{l}\text { Liver } \\
\text { function } \\
\text { tests }\end{array}$ & $\begin{array}{c}\text { Serum } \\
\text { total } \\
\text { cholesterol }\end{array}$ \\
\hline I & $\mathrm{m}$ & 54 & wid & Wet & mrk & Much & $?$ & ? & nor \\
\hline 2 & $\mathrm{~m}$ & 47 & wid & Wet & mrk & Much & $i$ & $?$ & elv \\
\hline 3 & $\mathrm{~m}$ & 47 & wid & Dry & mrk & Less & Sal & nor & nor \\
\hline 4 & f & 40 & loc & Dry & mrk & Less & ? & nor & elv \\
\hline 5 & $f$ & 69 & wid & Wet & mrk & Much & Sau & nor & elv \\
\hline 6 & $\mathrm{~m}$ & 42 & wid & Dry & slg & Less & $?$ & $?$ & nor \\
\hline 7 & f & 71 & wid & Wet & mrk & Less & $?$ & $?$ & $?$ \\
\hline 8 & f & 21 & wid. & Wet & mrk & Less & ? & $?$ & $?$ \\
\hline 9 & $\mathrm{~m}$ & 49 & loc & Dry & $\mathrm{mrk}$ & Less & $?$ & ? & elv \\
\hline 10 & $\overline{\mathrm{m}}$ & 15 & loo & Wet & slg & Less & ? & $?$ & nor \\
\hline 11 & $\mathrm{~m}$ & 42 & loc & Dry & mrk & Less & ? & ? & nor \\
\hline 12 & $\overline{\mathrm{m}}$ & 63 & wid & Dry & mrk & Much & ? & ? & elv \\
\hline 13 & $\mathrm{~m}$ & 31 & loc & Wet & slg & Much & $?$ & $?$ & $?$ \\
\hline 14 & $\mathrm{~m}$ & $2 \mathrm{mos}$ & wid & Wet & mrk & Less & $?$ & ? & $?$ \\
\hline 15 & $f$ & 15 & loc & Wet & mrk & Much & $\mathrm{Sau}$ & $?$ & ? \\
\hline 16 & $\mathrm{~m}$ & 36 & loc & Dry & $\mathrm{mrk}$ & Less & Sau & ? & ? \\
\hline \multicolumn{7}{|c|}{$\begin{aligned} \mathbf{m} & =\text { Male } \\
\mathbf{f} & =\text { Female } \\
\text { wid } & =\text { Widespread } \\
\text { loc } & =\text { Localized }\end{aligned}$} & \multicolumn{3}{|c|}{$\begin{aligned} \text { mrk } & =\text { Marked } \\
\text { slg } & =\text { Slight }\end{aligned}$} \\
\hline
\end{tabular}




\section{DISCUSSION}

The active principles responsible for the positive reaction of immunodiffusion, PCA and fluorescent antibody staining may be called precipitating antibody, PCA antibody and cellular antibody, respectively.

Although the significance of the precipitating antibody is obscure, it might be produced against some constituent in the seborrheic scales, or might indicate a false positive precipitation, as the precipitation reaction were generally very faint except the $(2+)$ reaction of Case 1 . In view of the work of Sindo ${ }^{18}$ and of Hosoda ${ }^{19}$ who demonstrated an incomplete antibody in the serum in delayed hypersensitivity, the PCA antibody may indicate the presence of delayed hypersensitivity to the squamal antigen. The cellular antibody demonstrated by fluorescent antibody technique is a direct evidence for the existence of contact allergy to the seborrheic scales.

Then, what will be the clinical significance of these three antibodies? To answer this question, I analyzed the relationship between these antibodies and the clinical pictures of individual cases (Tables 8 and 9). Although no significant correlation between the antibodies and the clinical pictures was confirmed because of insufficient number of cases, an outline of correlation was found in the following way: all the items of the clinical pictures were grouped into those which were observed only in the antibody-positive cases and not in the negative ones (A), and those which were observed only in the antibody-negative cases and not

seorrhoeicum-scale antibodies in individual cases

\begin{tabular}{|c|c|c|c|c|}
\hline \multirow[b]{2}{*}{ Total duration } & \multirow{2}{*}{$\begin{array}{l}\text { Anti-allergic } \\
\text { therapy before } \\
\text { experiment }\end{array}$} & \multicolumn{3}{|c|}{ Antibodies } \\
\hline & & $\begin{array}{l}\text { Precipitating } \\
\text { antibody }\end{array}$ & PCA antibody & $\begin{array}{l}\text { Cellular } \\
\text { antibody }\end{array}$ \\
\hline Over 2 yrs & Not done & $(+)$ & $(+)$ & $?$ \\
\hline Over 10 yrs & Not done & $(-)$ & $(+)$ & $?$ \\
\hline Over 5 yrs & Done & $(-)$ & $(\rightarrow)$ & $(-)$ \\
\hline Over $9 \operatorname{mos}$ & Done & $(-)$ & $(+)$ & $?$ \\
\hline Over 2 yrs & Not done & $(+)$ & $(+)$ & $?$ \\
\hline Over 16 yrs & Not done & $(+)$ & $(+)$ & $?$ \\
\hline Cured in 4 mos & Done & $(-)$ & $(t)$ & $?$ \\
\hline Over 6 yrs & Done & $(-)$ & $(-)$ & $?$ \\
\hline Over 1 yrs & Done & $(-)$ & $?$ & $(+) \rightarrow( \pm) \dagger$ \\
\hline Over 3 yrs & Done & $(+)$ & $(+)$ & $(-)$ \\
\hline Over 7 mos & Done & $(-)$ & $(-)$ & $(-)$ \\
\hline Unknown* & Done & $(+)$ & $(+)$ & $(t)$ \\
\hline Over 2 yrs & Unknown & $(-)$ & $(-)$ & $?$ \\
\hline Cured in 2 mos & Done & $?$ & $(-)$ & $?$ \\
\hline Over $7 \mathrm{mos}$ & Unknown & $?$ & $?$ & $(+)$ \\
\hline Over $7 \mathrm{mos}$ & Unknown & $?$ & $?$ & $(+)$ \\
\hline Sal=Staph. albus & \multirow{4}{*}{\multicolumn{2}{|c|}{$\begin{aligned} * & =\text { Accidental death } \\
& \text { in the 3rd month } \\
& +(+) \text {, but }( \pm) \\
& \text { after treatment }\end{aligned}$}} & & \\
\hline $\mathrm{Sau}=\mathrm{Staph}$. aureus & & & & \\
\hline nor $=$ Normal & & & & \\
\hline elv = Elevated & & & & \\
\hline
\end{tabular}


TABLE 9. Relationship between anti-eczema seborrhoeicum-scale antibodies and clinical pictures

\begin{tabular}{|c|c|c|c|c|c|c|c|}
\hline \multirow{2}{*}{\multicolumn{2}{|c|}{ Antibody }} & $\begin{array}{l}\text { Precipitating } \\
\text { antibody }\end{array}$ & \multicolumn{2}{|c|}{$\begin{array}{c}\text { PCA } \\
\text { antibody }\end{array}$} & \multicolumn{3}{|c|}{$\begin{array}{l}\text { Cellular } \\
\text { antibody }\end{array}$} \\
\hline & & $(+)(-)$ Total & $(+)(-$ & -) Total & $(+)$ & $(-)$ & Total \\
\hline \multirow{2}{*}{ Sex } & Male & $4(2) 5(1) 9(3)$ & $5(3)$ & $49(3)$ & 3 & 3 & 6 \\
\hline & Female & $1(1) 2(0) 4(1)$ & $3(1)$ & $14(1)$ & 1 & 0 & 1 \\
\hline \multirow{3}{*}{ Age } & Under 15 yrs & $\begin{array}{lll}1(0) & 0 & 1(0)\end{array}$ & $1(0)$ & $12(0)$ & 1 & 1 & 2 \\
\hline & $16-50 \mathrm{yrs}$ & $1(1) 7(1) 8(2)$ & $3(2)$ & $4 \quad 7(2)$ & 2 & 2 & 4 \\
\hline & Over 51 yrs & $3(2) \quad 1(0) \quad 4(2)$ & $4(2)$ & $0 \quad 4(2)$ & 1 & 0 & 1 \\
\hline \multirow{2}{*}{$\begin{array}{l}\text { Distribution } \\
\text { of the lesion }\end{array}$} & Widespread & $4(3) \quad 4(1) \quad 7(4)$ & $6(4)$ & $9(4)$ & 1 & 1 & 2 \\
\hline & Localized & $1(0) \quad 4(0) 6(0)$ & $2(0)$ & $4(0)$ & 3 & 2 & 5 \\
\hline \multirow{2}{*}{$\begin{array}{l}\text { Nature } \\
\text { of the lesion }\end{array}$} & Wet & $3(2) \quad 4(1) 7(3)$ & $5(3)$ & $38(3)$ & 1 & 1 & 2 \\
\hline & Dry & $2(1) \quad 4(0) 5(1)$ & $3(1)$ & $5(1)$ & 3 & 2 & 5 \\
\hline \multirow{2}{*}{$\begin{array}{l}\text { Redness of the } \\
\text { lesion }\end{array}$} & Marked & $3(2) 7(1) 10(3)$ & $6(3)$ & $4 \quad 0(3)$ & 4 & 2 & 6 \\
\hline & Slight & $2(1) \quad 1(0) 3(1)$ & $2(1)$ & $3(1)$ & 0 & 1 & 1 \\
\hline \multirow{2}{*}{$\begin{array}{l}\text { Scale of the } \\
\text { lesion }\end{array}$} & Much & $3(2) 2(1) 5(3)$ & $4(3)$ & $15(3)$ & 2 & 0 & 2 \\
\hline & Less & $2(1) 6(0) 8(1)$ & $4(1)$ & $8(1)$ & 2 & 3 & 5 \\
\hline \multirow{3}{*}{$\begin{array}{l}\text { Bacteria of } \\
\text { secondary } \\
\text { infection }\end{array}$} & Staph. aureus & $\begin{array}{lll}1(1) & 0 & 1(1)\end{array}$ & $1(1)$ & $0 \quad 1(1)$ & 2 & 0 & 2 \\
\hline & Staph. albus & $0 \quad 1(0) 1(0)$ & & $1 \quad 1(0)$ & 0 & 1 & 1 \\
\hline & Not examined & $4(2) \quad 7(1) 11(3)$ & $7(3)$ & $3 \quad 11(3)$ & 2 & 2 & 4 \\
\hline \multirow{3}{*}{$\begin{array}{l}\text { Liver function } \\
\text { tests }\end{array}$} & Normal & $1(1) 2(0) 3(1)$ & $2(1)$ & $13(1)$ & 0 & 1 & 1 \\
\hline & Impaired & $\begin{array}{lll}0 & 0 & 0\end{array}$ & & $\begin{array}{ll}0 & 0(0)\end{array}$ & 0 & 0 & 0 \\
\hline & Not examined & $4(2) 6(1) 10(3)$ & $6(3)$ & $410(3)$ & 4 & 2 & 6 \\
\hline \multirow{3}{*}{$\begin{array}{l}\text { Serum total } \\
\text { cholesterol }\end{array}$} & Normal & $3(2) 2(0) 5(2)$ & $3(2)$ & $5(2)$ & 0 & 3 & 3 \\
\hline & Elevated & $2(1) 3(1) 5(2)$ & $4(2)$ & $4(2)$ & 2 & 0 & 2 \\
\hline & Not examined & $\begin{array}{lll}0 & 3(0) & 3(0)\end{array}$ & $1(0)$ & $4(0)$ & 2 & 0 & 2 \\
\hline \multirow{3}{*}{$\begin{array}{l}\text { Total } \\
\text { duration }\end{array}$} & Under 6 months & $0 \quad 1(0) 1(0)$ & $1(0)$ & $12(0)$ & 0 & 0 & 0 \\
\hline & Over 7 months & $4(3) 7(1) 11(4)$ & $6(4)$ & $410(4)$ & 3 & 3 & 6 \\
\hline & Unknown (death) & $1(0) \quad 0 \quad 1(0)$ & $1(0)$ & $0 \quad 1(0)$ & I & 0 & 1 \\
\hline \multirow{3}{*}{$\begin{array}{l}\text { Anti-allergic } \\
\text { therapy before } \\
\text { experiment }\end{array}$} & Done & 6 & 4 & 8 & 2 & 3 & 5 \\
\hline & Not done & 1 & 4 & 0 & 0 & 0 & 0 \\
\hline & Unknown & 0 & 0 & 1 & 2 & 0 & 2 \\
\hline \multicolumn{2}{|c|}{ Total } & $5(3) 8(1) 13(4)$ & $8(4)$ & $5 \quad 13(4)$ & $4(0)$ & $3(0)$ & $7(0)$ \\
\hline
\end{tabular}

( ): The numbers of those cases in which the so-called anti-allergic therapy had not been performed before experiment. 
in the positive ones (B). However, I found that no items of the clinical pictures corresponded to either (A) or (B) in those cases submitted to examination of the precipitating antibody and the PCA antibody. In the cases examined for the presence of the cellular antibody, there were no (A) items, but only one item that belonged to (B): that is, the normal serum total cholesterol (Table 9).

In the above observations there were included some cases which had received before experiment the so-called anti-allergic agents, such as adrenocorticosteroids, antihistaminics, antiserotonics and nonspecific desenstitizing drugs. Since this anti-allergic therapy may affect more or less the production of antibodies, a further analysis of the clinical pictures was made in those cases in which no such therapy had been performed. The numbers in the parentheses in Table 9 indicate the numbers of such cases. Because all the cases examined for the presence of the cellular antibody had been treated with the anti-allergic agents, it was impossible to analyze the relationship between the clinical pictures and the cellular antibody. Among those cases submitted to examination of the precipitating antibody, four cases had not received anti-allergic therapy. In one of them the precipitating antibody was negative. The clinical pictures of these cases were analyzed in the way described above, but no items corresponded to either (A) or (B). In the series of experiments on the PCA antibody, the anti-allergic therapy had not been performed in 4 cases. In all of them this antibody was positive. However, as the lesions in these 4 cases were widespread and so recurrent or intractable that the total course covered more than 7 months, this antibody is expected to be limited to those cases with such clinical pictures. Furthermore, in 3 of these 4 cases the lesion was characterized by oozing, marked redness and excessive scaling. These results strongly suggest the development of contact allergy to the autologous seborrheic scale in those cases in which the lesion is widespread and the illness is so intractable that the duration covers more than 7 months. Moreover, the lesion may be characterized by weeping, redness and excessive scaling.

Though not all the criteria of autoimmune disease presented by Witebsky et $a{ }^{20}$ were satisfied by the present data, I believe the results of the present study suggest the possibility that a contact allergy to the autologous seborrheic scales develops in some cases of ES, which was already anticipated by Dohi, Ito and Haxthausen. This autoimmune phenomenon may play an important role in generalization and eczematization, or in intractability of the lesions of eczema seborrhoeicum.

\section{Acknowledgment}

I wish to express my thanks to Prof. Y. Katabira for his constant interest and guidance in this investigation. 


\section{References}

1) Katabira, Y. Skin manifestations in the seborrhoic areas IV. Difficulty in treatment of eczema seborrhoicum. Jap. J. Dermat. (Jap.), 1956, 66, 694-701.

2) Ohno, T. On eczema on the head of the children. Jap. J. Dermat. (Jap.), 1907, 7, 298-302.

3) Aoki, D. Difficulty in treatment of eczema of the children. Chiryo oyobi Syoho (Jap.), 1912, 2, 163-173 and 267-273.

4) Dohi, K. Eczema faciei. Hihukagaku (Jap.), Vol. 1. Asakaya, Tokyo, 1913, pp. 370-372.

5) Dohi, K. Eczema seborrhoicum. Hihukagaku (Jap.), Vol. 1, Asakaya, Tokyo, 1913, 393-396.

6) Ito, M. Problems on eczema infantum. Tokyo Izi Sinsi (Jap.), 1952, 69, 117-118.

7) Darier, J. Eczématides. Précis de dermatologie. Masson et $\mathrm{C}^{i e}$, Paris, 1923, pp. 90-100.

8) Davies, J.H.T. Seborrhoeic eczema: An attempt to define the scope of the term. Brit. J. Dermat., 1952, 64, 213-224.

9) Scott, A.J. Allergy and seborrhoea, Lewis, London, 1955.

10) Haxthausen, H. Allergic phenomena in pityriasis simplex (seborrheic dermatitis). Progress in allergy, Vol. 2, Basel-New York, Kallós, 1949, pp. 220-222.

11) Sato, W. On the correlationship between the gingival symptom (Miura) and the blood complement activity. Jap. J. Dermat. (Jap.), 1961, 71, 1177-1183.

12) Chihara, R. Ueber die Antigenität der Menschenhaut, deren Anhangsorgane und der Produkte derselben bei der Stormreaktion. Hihu to Hinyo (Jap.), 1938, 6, 396-405.

13) Coca, A.F. Cited by Kuroyanagi, T. Preparation of antigen infusions. Rinsyo arerugi (Jap.), Igaku Syoin, Tokyo, 1956, 142.

14) Nowotny, A., Lüderitz, O. \& Westphal, O. Rundfilter-Chromatographie langkettiger Fettsäuren bei der Analyse bakterieller Lipopolysaccharide. Biochem. Z., 1958, $330,47-52$.

15) Aswaq, M., Farber, E.M., Moreci, A.P. \& Raffel, S. Immunologic reactions in psoriasis. Arch. Dermat., 1960, 82, 663-666.

16) Ishida, N., Hinuma, Y. \& Ohta, R. Practice of fluorescent antibody technique $I$. Rinsyo Byori, (Jap.), 1961, 9, 470-476.

17) Ishida, N., Hinuma, Y. \& Miyamoto, T. Practice of fluorescent antibody technique II. Rinsyo Byori (Jap.) 1962, 10,60-66.

18) Sindo, T. Antigen-antibody reaction in system of mycobacterium tuberculosis. Jap. J. Bact. (Jap.), 1958, 13, 460-578.

19) Hosoda, Y. Comparative studies on tuberculous antibodies in sera, skin tissue and lymphnodes, and results of tuberculin skin reaction examined in guinea pigs inoculated with heat-killed tubercle bacilli. Arerugi (Jap.), 1958, 7, 219-225 and 235-236.

20) Witebsky, E., Rose, N.R., Terplan, K., Paine, J.R. \& Egan, R.W. Chronic thyroiditis and autoimmunization. J. Amer. med. Ass., 1957, 164, 1439-1447. 


\section{Explanation of Figures}

Fig. 2. Ouchterlony's diffusion-in-gel method.

The precipitation reaction of the undiluted serum and the $1: 2$ dilution of serum in the upper two peripheral wells against the scale infusion Ag-ES1 in the central well.

Fig. 3. Passive cutaneous anaphylaxis.

A kind of delayed reaction in the upper left site. The reaction is read as $(2+)$.

Fig. 4. Fluorescent antibody staining (complement method).

Nonspecific fluorescence in the epidermis of the involved skin from a patient with eczema seborrhoeicum. $10 \times 10$.

Fig. 5. Fluorescent antibody staining (specific method). Specific fluorescence in the basal layer of the involved skin from a patient with eczema seborrhoeicum. $10 \times 20$. 


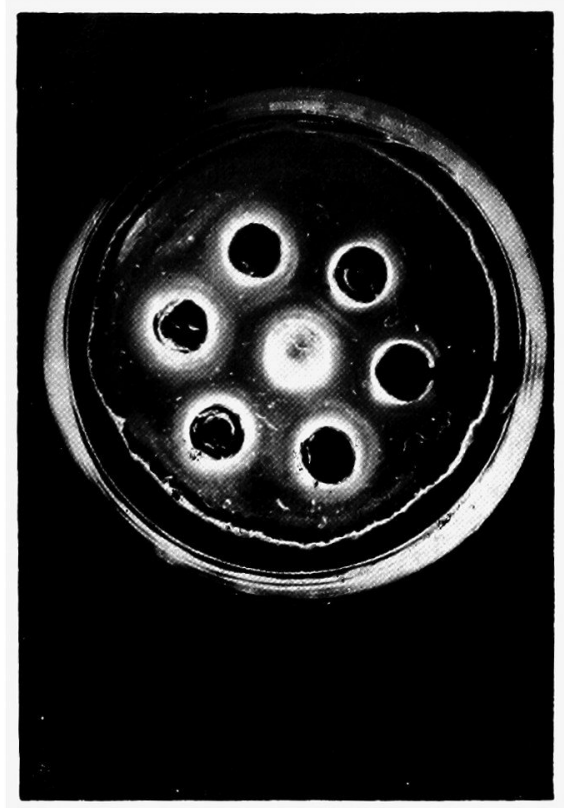

Fig. 2.

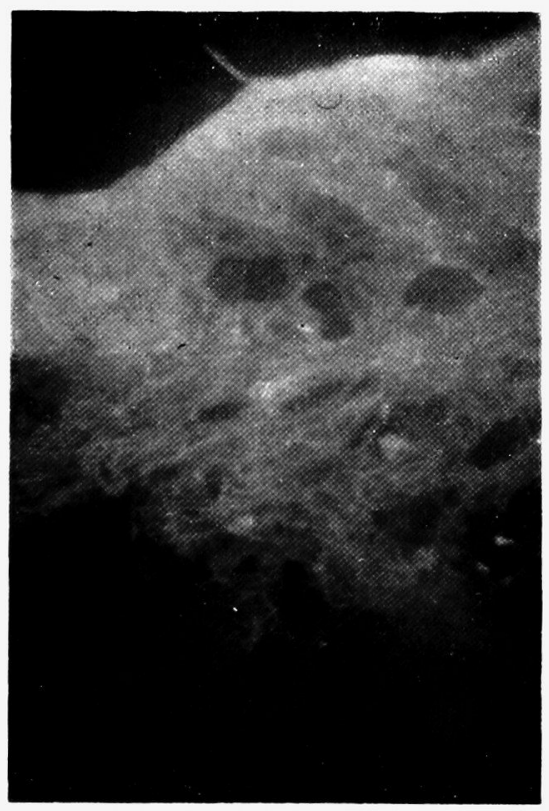

Fig. 4.

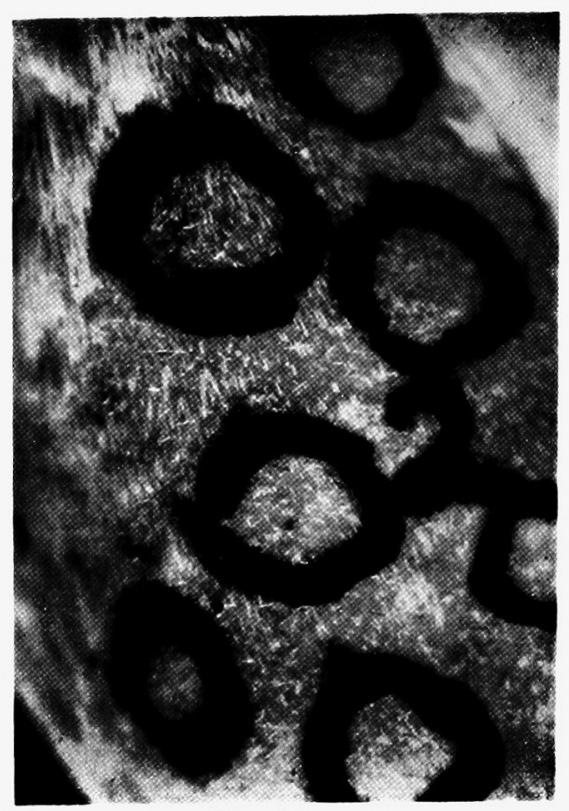

Fig. 3.

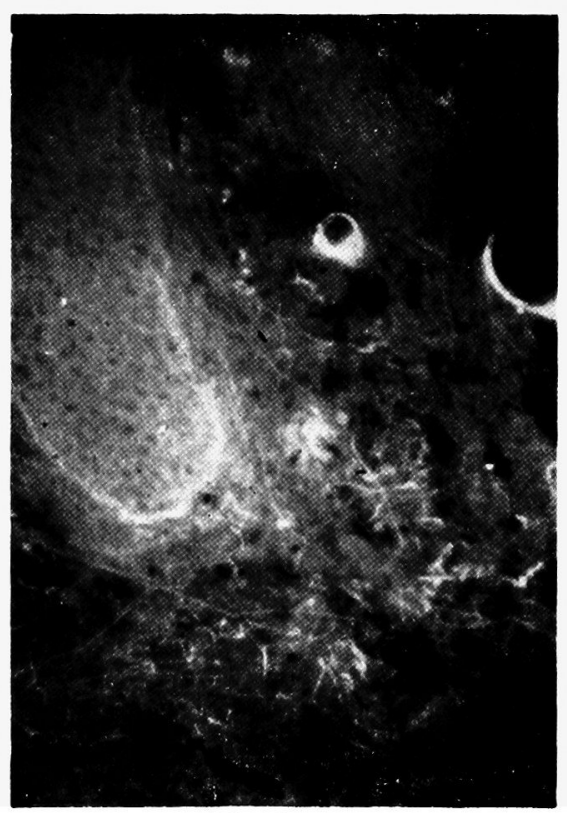

Fig. 5. 